\title{
Identification of the transcripts associated with spontaneous HCV clearance in individuals co-infected with HIV and HCV
}

Yue Chen ${ }^{1 *}{ }^{*}$, Chengli Shen ${ }^{1 \dagger}$, Debjani Guha ${ }^{1}$, Ming Ding ${ }^{1}$, Scott Kulich², Aiymkul Ashimkhanova', Charles Rinaldo ${ }^{1}$, Eric Seaberg ${ }^{3}$, Joseph B. Margolick ${ }^{3}$, Valentina Stosor ${ }^{4}$, Otoniel Martínez-Maza ${ }^{5}$ and Phalguni Gupta ${ }^{1}$

\begin{abstract}
Background: Infection with human immunodeficiency virus (HIV) influences the outcome and natural disease progression of hepatitis $\mathrm{C}$ virus ( $\mathrm{HCV}$ ) infection. While the majority of HCV mono-infected and HCV/HIV co-infected subjects develop chronic HCV infection, 20-46\% of mono- and co-infected subjects spontaneously clear HCV infection. The mechanism underlying viral clearance is not clearly understood. Analysis of differential cellular gene expression (mRNA) between HIV-infected patients with persistent HCV infection or spontaneous clearance could provide a unique opportunity to decipher the mechanism of HCV clearance.

Methods: Plasma RNA from HIV/HCV co-infected subjects who cleared HCV and those who remained chronically infected with HCV was sequenced using lon Torrent technology. The sequencing results were analyzed to identify transcripts that are associated with HCV clearance by measuring differential gene expression in HIV/HCV co-infected subjects who cleared HCV and those who remained chronically infected with HCV.

Results: We have identified plasma mRNA, the levels of which are significantly elevated (at least 5 fold, False Discovery Rate (FDR) $<0.05$ ) before HCV infection in subjects who cleared HCV compared to those who remained chronically infected. Upon further analysis of these differentially expressed genes, before and after HCV infection, we found that before HCV infection 12 genes were uniquely upregulated in the clearance group compared to the chronically infected group. Importantly, a number of these 12 genes and their upstream regulators (such as CCL3, IL17D, LBP, SOCS3, NFKBIL1, IRF) are associated with innate immune response functions.
\end{abstract}

Conclusions: These results suggest that subjects who spontaneously clear HCV may express these unique genes associated with innate immune functions.

Keywords: HIV/HCV coinfection, Clearance of HCV infection, Chronic HCV infection, Plasma RNA sequencing, Sequence analysis

\section{Background}

Hepatitis $\mathrm{C}$ virus (HCV) infection is the leading cause of hepatocellular carcinoma in the United States [1]. Due to similar transmission routes, approximately one third of HIV-infected individuals are co-infected with $\mathrm{HCV}$ [2-4]. In HCV mono infection, nearly $70-80 \%$ of infected individuals develop chronic infection and liver

\footnotetext{
*Correspondence: cheny@pitt.edu

${ }^{\dagger}$ Equal contributors

'Department of Infectious Diseases and Microbiology, Graduate School of Public Health, University of Pittsburgh, 2138 Parran Hall, 130 DeSoto Street, Pittsburgh, Pa 15261, USA

Full list of author information is available at the end of the article
}

cirrhosis, some of whom develop hepatocellular carcinoma, while $20-30 \%$ of infected individuals spontaneously clear the viral infection within one year of infection [5]. However, in HIV/HCV co-infected individuals, infection with HIV is associated with a decrease in the rate of spontaneous HCV clearance, exacerbates the natural course of HCV infection, and accelerates the development of HCC [6-10]. Currently, the mechanism of spontaneous HCV clearance and how HIV might affect this are not clear. Certain immunological components have been shown to be involved in HCV clearance [11-13]. An HCV-specific T-cell response in the liver has also been 
reported to be associated with $\mathrm{HCV}$ clearance. Various factors, such as gene polymorphisms in interleukin 28B (IL28B) and IP-10 have been implicated in mediating host susceptibility/resistance to $\mathrm{HCV}$ infection and disease progression [14-17]. In HCV-infected chimpanzees, interleukin binding factor 3 (ILF3) and cytotoxic granule associated cRNA binding protein (TIA1), which are associated with robust T-cell responses, were highly induced in animals who cleared the virus [18]. However, these represent only a few of the many factors that are potentially involved in $\mathrm{HCV}$ clearance.

Differential cellular gene expression in HIV-infected subjects has been shown to be associated with HIV disease progression [19]. Therefore, analysis of differential cellular gene expression between HIV infected patients with persistent $\mathrm{HCV}$ infection and those with spontaneous clearance of this virus could provide a unique opportunity to decipher the mechanism of HCV clearance in HIV/HCV co-infected subjects.

Pathogenic changes occurring in any tissues or organs are expected to leave footprints in the blood. Consequently, measurement of certain target RNA in the plasma has been explored or used for diagnosis of a number of diseases and cancers [20-24]. We hypothesize that the cellular (immunological and non-immunological) factors that are responsible for spontaneous $\mathrm{HCV}$ clearance leave footprints in the plasma, leading to differential plasma RNA expression profiles between those who spontaneously clear HCV infection and chronically infected individuals, with or without HIV co-infection. It is presumed that differential gene expression in plasma between those who cleared HCV and those who remained chronically infected will provide clues to the mechanism of HCV clearance. Due to the low quantity of RNA in blood plasma, currently there is no convenient way to characterize plasma RNA profiles. Recent advancement of next-generation sequencing technologies has made it possible for unbiased and comprehensive analysis of the gene expression from both cells and tissues. We have recently modified the NGS technology in Ion Proton platform and characterized RNA profiles in plasma.

In this study we identified plasma mRNA, the levels of which are significantly increased (at least 5 fold, FDR $<0.05$ ) in the HCV clearance group compared to chronically $\mathrm{HCV}$ infected patients. Upon further analysis of these differentially expressed genes, we have identified 12 genes that are upregulated only in clearance group before $\mathrm{HCV}$ infection. Moreover, some of these 12 genes and their upstream regulators are associated with innate immune functions.

\section{Methods}

\section{Patients and samples}

Frozen plasma samples were obtained from $13 \mathrm{HCV}$ seroconverters who were infected with HIV for more than 10 years before HCV seroconversion in the Multicenter AIDS Cohort Study (MACS) [25]. MACS is the first and largest study specifically created to examine the natural history of AIDS. MACS participants are seen every six months and at each visit, plasma is taken for storage at $-80{ }^{\circ} \mathrm{C}$. $\mathrm{HCV}$ seroconversion is defined by the $\mathrm{HCV}$ antibody switching from negative to positive in plasma and the plasma $\mathrm{HCV}$ antibody positivity were persistent for all subsequent visits of the individuals. Furthermore, $\mathrm{HCV}$ seroconversion visits were confirmed by reverse transcriptase polymerase chain reaction specific for detecting HCV RNA. Spontaneous HCV clearance is defined as plasma HCV RNA were never detected or detected only one to two times around the time of seroconversion. Chronic HCV infection was defined as plasma HCV RNA being persistently detected for more than fiveten years. From five subjects with spontaneous HCV clearance and eight subjects with chronic $\mathrm{HCV}$ infection, we examined their plasma samples that were obtained immediately before and after HCV infection (MACS visits are six months apart). All HCV infections were reported to have been acquired by sexual transmission. At the time of $\mathrm{HCV}$ infection, all subjects were naive to antiretroviral therapy and anti-HCV treatment.

\section{Nucleic acid extraction, cDNA library construction and sequencing}

Total nucleic acids were extracted from $1 \mathrm{ml}$ of frozen cryopreserved plasma using an automated NucliSens EasyMag nucleic acid extraction machine (bioMérieux, Durham, NC) followed by removal of DNA from the nucleic extract with Qiagen AllPrep DNA/RNA mini kit and ribosomal RNA by a Low Input RiboMinus System (Life Technologies). The cDNA Library was then constructed using an Ion Torrent Total RNA-Seq Kit (Life Technologies) for whole transcriptome libraries and Barcodes 1 through 8 from an Ion Xpress 1-16 barcoding kit were used (Life Technologies) for each individual sample. cDNA libraries were quantified by qPCR using an Ion Library Quantitation Kit (Life Technologies) to determine a suitable template dilution factor for subsequent emulsion PCR and sequencing.

Four barcoded samples were combined for one sequencing reaction. Template preparation for sequencing was conducted using the OneTouch Ion $^{\text {tx }}$ Template Kit in the OneTouch machine (Life Technologies). Ion Torrent sequencing was conducted using the Ion Proton Sequencing Kit (Life Technologies) on an Ion Proton Machine (Life Technologies) using a P1(v2)-chip (Life Technologies). The constructed cDNA was also used for HIV viral load measurement using a quantitativereal time PCR for HIV gag RNA, with a sensitivity of 10 copies/mL [26]. 


\section{Sequence analysis}

Raw sequencing reads in FastQ format were assessed for quality using CLC Genomics Workbench 7. Reads were accepted based on the length (longer than 25 nucleotides) and number of ambiguous bases (Phred Quality Score higher than 20). Quality trimming was performed. The mean numbers of reads from different groups after trimming ranged from 3.2 million to 8.4 million. The trimmed reads were then mapped to Homo sapiens gene sequences based on Homo sapiens (hg19) mRNA.

Bioconductor edge $\mathrm{R}$ in $\mathrm{R}$ package was employed to perform the differential expression analysis. A general linear model was applied on the subjects before and after $\mathrm{HCV}$ infection to accommodate the multifactor design of the experiment. The model incorporates the main effect for $\mathrm{HCV}$ infection plus interactions with patients and viral clearance, thus allowing us to identify genes differentially expressed in $\mathrm{HCV}$ cleared and chronically infected patients before and after HCV infection. To ensure there were sufficient counts for each gene in the test, genes with mean read counts higher than 10 were kept in the analysis. Genes with BenjaminiHochberg adjusted FDR $<0.05$ and fold change greater than 1 were considered as significant genes. The significance and function networks of the detected differentially expressed genes were analyzed using Ingenuity Pathway Analysis software. The gene function information was obtained from GeneCards Human Gene Database (www.genecards.org).

\section{Results}

\section{Characteristics of study participants}

A total of 26 plasma samples from the $13 \mathrm{HCV}$ seroconverters obtained within six months before and after $\mathrm{HCV}$ infection were analyzed for plasma transcriptome profiles. All the participants were HIV positive for more than 10 years before HCV infection occurred. Four of the five participants who spontaneously cleared HCV infection had the CC variant of the IL28B gene, while the remaining one had the TT variant. In contrast, half of eight participants who became chronically infected by $\mathrm{HCV}$ had the CC variant IL28B gene and the remaining participants had the $\mathrm{CT}$ variant. For the 5 individuals with spontaneous $\mathrm{HCV}$ clearance, $\mathrm{HCV}$ loads were undetectable at the first $\mathrm{HCV}$ antibody positive visits. In contrast, the eight participants with chronic HCV infection had a median plasma HCV load of $1.6 \times 10^{7}$ copies $/ \mathrm{ml}$ at the first HCV RNA positive visit, with values ranging from $1.22 \times 10^{6}$ to $7 \times 10^{7}$ (Table 1 ). In the HCV clearance group, the HIV viral load was below 40 copies $/ \mathrm{ml}$ in three of the five patients and $>71,000$ copies $/ \mathrm{ml}$ in two participants both before and after HCV seroconversion. In the chronically $\mathrm{HCV}$ infected group, HIV viral load ranged
Table 1 Clinical characteristics of the study subjects

\begin{tabular}{lclll}
\hline $\begin{array}{l}\text { HCV Clearance Group } \\
\text { Patient ID }\end{array}$ & HCV infection & HCV load & HIV load & $\begin{array}{l}\text { Polymorphism of } \\
\text { IL28B gene }\end{array}$ \\
1 & - & $<43$ & $<40$ & CC \\
1 & + & $<43$ & $<40$ & \\
2 & - & $<43$ & $<40$ & $\Pi$ T \\
2 & + & $<43$ & $<40$ & \\
3 & - & $<43$ & $1,678,080$ & CC \\
3 & + & $<43$ & $3,598,880$ & \\
4 & - & $<43$ & 71,680 & CC \\
4 & + & $<43$ & 144,480 & \\
5 & - & $<43$ & $<40$ & CC \\
5 & + & $<43$ & $<40$ &
\end{tabular}

\section{HCV Chronic Infection Group}

\begin{tabular}{lllll} 
Patient ID & HCV infection & HCV load & HIV load & $\begin{array}{l}\text { Polymorphism of } \\
\text { IL28B gene }\end{array}$ \\
11 & - & $<43$ & 129,080 & CT \\
11 & + & $1.22 \times 10^{6}$ & 316,240 & \\
12 & - & $<43$ & 360 & $C T$ \\
12 & + & $70 \times 10^{6}$ & 50,840 & \\
13 & - & $<43$ & 81,240 & CC \\
13 & + & $7.55 \times 10^{6}$ & 17,480 & \\
14 & - & $<43$ & 136,760 & CC \\
14 & + & $3.93 \times 10^{6}$ & 1,040 & \\
15 & - & $<43$ & 73,840 & $C C$ \\
15 & + & $13.3 \times 10^{6}$ & 21,280 & \\
16 & - & $<43$ & 465,720 & $C T$ \\
16 & + & $18.9 \times 10^{6}$ & 170,120 & \\
17 & - & $<43$ & 138,520 & CC \\
17 & + & $4.8 \times 10^{6}$ & 331,560 & \\
18 & - & $<43$ & 51,400 & CT \\
18 & + & $7.33 \times 10^{6}$ & 18,240 & \\
\hline
\end{tabular}

Minimal detection limit of HIV measurement: 40 copies $/ \mathrm{ml}$ Minimal detection limit of HCV measurement: 43 copies $/ \mathrm{ml}$

from 360 to 465,000 copies/ml (mean 125,233 copies/ml) (Table 1).

Plasma mRNA profile of HIV-infected individuals with HCV clearance and those with chronic infection

Plasma transcriptome analysis was performed in $\mathrm{HCV}$ infected individuals who cleared virus and those who remained chronically infected. A schematic diagram of the approaches for measurement of differentially expressed genes from the patients' plasma samples collected before and after HCV infection and those cleared HCV and those who remained chronically infected is shown in Fig. 1. A comparison of transcriptomes before $\mathrm{HCV}$ infection 


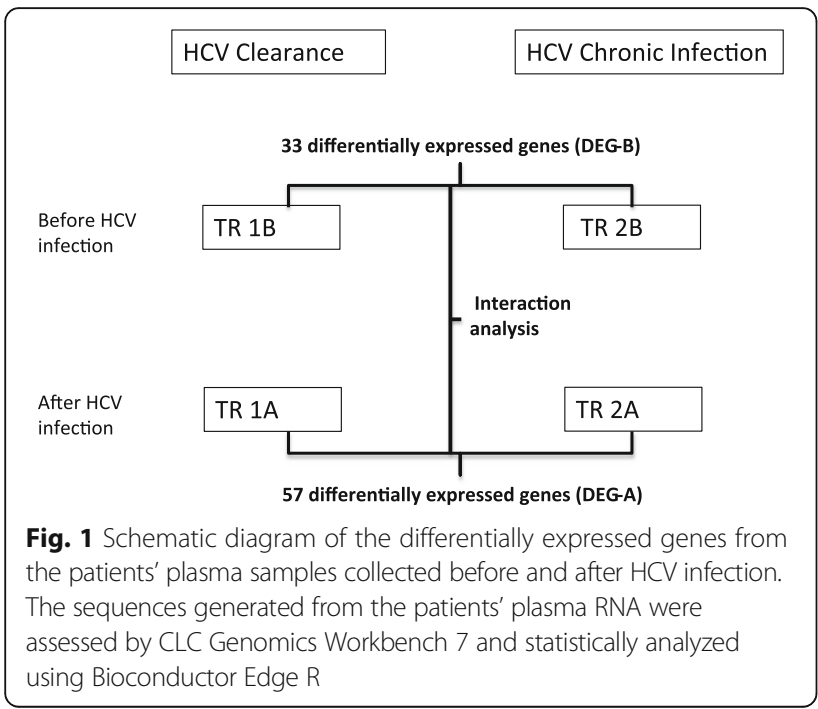

between the HCV clearance group (TR1B, Fig. 1) and the chronically $\mathrm{HCV}$ infected group (TR 2B, Fig. 1) showed that the expression levels of 32 genes were significantly higher (5-563 fold) and expression level of one gene (LL22NC03-63E9.3) was significantly lower in the clearance group (Table 2). To further assess the clustering of subjects within the chronic and clearance groups and across the groups, hierarchical clustering was performed using the differentially expressed genes (Fig. 2a). Four of the eight chronically infected participants clustered together indicating a distinct gene expression pattern whereas the other four samples did not show a similar pattern. On the other hand, three of the five participants in the clearance group clustered indicating similar gene expression and the remaining two subjects had different gene expression. In both clearance and chronic groups, the characteristics of the samples that did not aggregate with the rest of the samples in the respective groups were not different with respect to HIV viral load or $I L 28 B$ polymorphism. This suggests that HIV viral load and IL28B polymorphism may not have an independent effect on the pattern of the gene expression.

Of the 33 genes that were differentially expressed (DEGs) before HCV infection, 19 DEGs have known biological functions (Gene Cards Human Gene Database (http://www.genecards.org/)): six gene products (18\%) (ATP6V1G2, LPAR1, GNAI1, CCL3, IL17D, SLC2A6) are related to signal transduction pathways and innate immune response,. eight gene products (24\%) (LBR, EARS2, RAB11FIP5, CHST10, PRPSAP1, PCMTD2, MCU, PRDM13) are involved in metabolism and protein trafficking, and five gene products (15\%) (ZFHX3, DAZ4, TLX3, HOXD13, NFKBIL1) are RNA/DNA binding proteins involved in gene regulation (Fig. 2b).
To determine the differential gene expression pattern in response to $\mathrm{HCV}$ infection, a similar analysis was performed between transcriptomes in the clearance group (TR1A, Fig. 1) and chronic infection group (TR2A, Fig. 1), after HCV infection (Fig. 1). The expression levels of 56 genes were significantly higher, and that of one gene was significantly lower, in TR1A compared to TR2A (Table 3). Hierarchical clustering of DEGs showed that genes from five patients who had chronic infection clustered together, while no such clustering pattern was observed in the clearance group (Fig. 3a).

Of the 56 DEGs in the HCV clearance group, 34 are known to encode biologically functional proteins. Of these 34 genes, 14 DEG gene products (25\%) (MIXL1, SLC30A3, SFRP5, NLRP13, IRS4, GNAI1, CMTM4, F10, LPAR1, ATP12A, TLX3, ATP6V1G2, NEURL, AP3B1) are known to participate in, or to be related to, signal transduction pathways and innate immune responses, twelve DEG gene products (21\%) (LBR, MTMR1, PPP1R3G, PRPSAP1, RAB11FIP5, MANEAL, MCU, ADPRHL1, PRDM13, DPY19L3, SLC51A, CHST10) are involved in metabolism and protein trafficking and eight DEG gene products (14\%) (ZFHX3, SOHLH1, TCF15, ZC3H8, ZXDB, TLX3, HOXD13, ZXDA) are RNA/DNA binding proteins involved in gene regulation (Fig. $3 \mathrm{~b}$ ). However, no DEG was identified between plasma samples analyzed before and after $\mathrm{HCV}$ infection, regardless whether they were from clearance group (TR1B vs. TR1A) or chronic group (TR 2B vs. TR 2A) (Fig. 1).

Intersection analyses between DEGs identified in the clearance group before $\mathrm{HCV}$ infection (DEG-B, Fig. 1) and after HCV infection (DEG-A, Fig. 1) indicate that 12 DEGs were uniquely expressed in clearance group before $\mathrm{HCV}$ infection and 36 DEGs were uniquely expressed after HCV infection (Fig. 4). There were 21 DEGs that were common between the two groups. IPA analyses of these unique 12 genes expressed before $\mathrm{HCV}$ infection indicate that a number of these genes and their upstream regulators are associated with innate immune response in the clearance group (Fig. 5a and b). Among them 14\% are involved in immune cell trafficking, $14 \%$ are involved in humoral immune response and $14 \%$ are involved in cell mediated immune response suggesting that most of the unique DEGs in the clearance group before infection may play a role in defending against the virus (Fig. 5a). For instance, cytokine (such as IL-1, IL-4, IL-6, IL-8, IL-9, IL-10, TNFR1, interferon) signaling, Toll like receptor (TLR) signaling, MAPK signaling, NF- $\mathrm{KB}$ signaling, and communication between innate and adaptive immune cells may be involved (Fig. 5b). Similar analyses with 36 DEGs after HCV infection found that these genes are involved in glucocorticoid receptor signaling, myc mediated apoptosis signaling, axonal guidance signaling, IGF1 signaling, MAPK 
Table 2 DEGs in plasma before HCV infection in clearance group compared to those in chronically infected group

\begin{tabular}{|c|c|c|c|c|}
\hline$D E G s^{a}$ & Gene function & Fold difference & $P$ value & FDR \\
\hline AD000091.2 & Uncharacterized & 563.4 & $2.83 \mathrm{E}-07$ & 0.001188912 \\
\hline C11orf95 & $\begin{array}{l}\text { Chromosome } 11 \text { open reading frame } 95 \text {. Diseases associated } \\
\text { with C11orf95 include ependymoma and chondroid lipoma. }\end{array}$ & 100.9 & $5.80 \mathrm{E}-07$ & 0.001188912 \\
\hline LPAR1 & $\begin{array}{l}\text { Lysophosphatidic acid receptor } 1 \text {. Its related pathways are } \\
\text { PI3K-Akt signaling pathway and Ras signaling pathway. }\end{array}$ & 20 & $6.66 \mathrm{E}-07$ & 0.001188912 \\
\hline LBR & $\begin{array}{l}\text { Lamin B receptor. Its related pathways are Metabolism } \\
\text { and Metabolism. }\end{array}$ & 20.6 & 2.85E-06 & 0.003815476 \\
\hline GNAI1 & $\begin{array}{l}\text { Guanine nucleotide binding protein (G protein), alpha inhibiting } \\
\text { activity polypeptide 1. Its related pathways are GPCR Pathway } \\
\text { and GPCR Pathway. }\end{array}$ & 7.6 & $9.21 \mathrm{E}-06$ & 0.008563212 \\
\hline HOXD13 & $\begin{array}{l}\text { Homeobox D13. This gene is related to sequence-specific DNA } \\
\text { binding transcription factor activity and chromatin binding. }\end{array}$ & 231.4 & $9.61 \mathrm{E}-06$ & 0.008563212 \\
\hline EARS2 & $\begin{array}{l}\text { Glutamyl-tRNA synthetase 2, mitochondrial. Its related pathways } \\
\text { are Metabolism and Gene Expression. }\end{array}$ & 22.6 & 1.17E-05 & 0.008563212 \\
\hline PRDM13 & $\begin{array}{l}\text { PR domain containing } 13 \text {. This gene related to } \\
\text { methyltransferase activity. }\end{array}$ & 30.4 & $1.28 \mathrm{E}-05$ & 0.008563212 \\
\hline RAB11FIP5 & $\begin{array}{l}\text { RAB11 family interacting protein } 5 \text { (class I). Its related pathways } \\
\text { are Endocytosis and Delta508-CFTR traffic/ER-to-Golgi in CF. }\end{array}$ & 23 & $2.52 \mathrm{E}-05$ & 0.013834245 \\
\hline CTC-504A5.1 & Affiliated with the ncRNA class & 16.6 & $2.58 \mathrm{E}-05$ & 0.013834245 \\
\hline CHST10 & $\begin{array}{l}\text { Carbohydrate sulfotransferase 10. Its related pathways are } \\
\text { Other types of O-glycan biosynthesis and Biological oxidations. }\end{array}$ & 8.9 & $4.28 \mathrm{E}-05$ & 0.019890845 \\
\hline PRPSAP1 & $\begin{array}{l}\text { Phosphoribosyl pyrophosphate synthetase-associated protein } 1 . \\
\text { This gene is related to magnesium ion binding and enzyme } \\
\text { inhibitor activity. }\end{array}$ & 10 & 4.46E-05 & 0.019890845 \\
\hline TLX3 & $\begin{array}{l}\text { T-cell leukemia homeobox } 3 \text {. Its related pathways are } \\
\text { Transcriptional misregulation in cancer and SIDS } \\
\text { Susceptibility Pathways. }\end{array}$ & 103.6 & $5.11 \mathrm{E}-05$ & 0.021040208 \\
\hline RP11-259G18.1 & Uncharacterized & 21.7 & $7.50 \mathrm{E}-05$ & 0.024582733 \\
\hline DAZ4 & $\begin{array}{l}\text { Deleted in azoospermia 1. This gene is related to this gene } \\
\text { include RNA binding and nucleotide binding. }\end{array}$ & 7 & $7.68 \mathrm{E}-05$ & 0.024582733 \\
\hline TMEM52 & Transmembrane protein 52 & 50.8 & $7.68 \mathrm{E}-05$ & 0.024582733 \\
\hline AC007879.2 & Uncharacterized & 13.3 & 7.93E-05 & 0.024582733 \\
\hline PCMTD2 & $\begin{array}{l}\text { Protein-L-isoaspartate (D-aspartate) O-methyltransferase domain } \\
\text { containing 2. This gene is related to protein-L-isoaspartate } \\
\text { (D-aspartate) O-methyltransferase activity. }\end{array}$ & 10.4 & $8.26 \mathrm{E}-05$ & 0.024582733 \\
\hline HNF1A-AS1 & HNF1A antisense RNA 1 affiliated with the antisense RNA class. & 13.6 & $8.86 \mathrm{E}-05$ & 0.024984166 \\
\hline SUV42OH2_1 & Uncharacterized & 21.7 & $9.76 \mathrm{E}-05$ & 0.026140534 \\
\hline ATP6V1G2 & $\begin{array}{l}\text { ATPase, } \mathrm{H}+\text { transporting, lysosomal } 13 \mathrm{kDa} \text {, V1 subunit } \mathrm{G} 2 \text {. } \\
\text { A multisubunit enzyme that mediates acidification of } \\
\text { intracellular compartments of eukaryotic cells. }\end{array}$ & 27.3 & $1.06 \mathrm{E}-04$ & 0.027114541 \\
\hline TCP10L & $\begin{array}{l}\text { T-complex 10-like. An important paralog of this gene is } \\
\text { TCP10L2. }\end{array}$ & 13.9 & $1.23 \mathrm{E}-04$ & 0.028632706 \\
\hline MCU & $\begin{array}{l}\text { Mitochondrial calcium uniporter. It is related to calcium } \\
\text { channel activity and uniporter activity. }\end{array}$ & 7.8 & 1.23E-04 & 0.028632706 \\
\hline ZFHX3 & $\begin{array}{l}\text { Zinc finger homeobox 3. Its related pathways are Transcriptional } \\
\text { Regulatory Network in Embryonic Stem Cell. }\end{array}$ & 8 & $1.59 \mathrm{E}-04$ & 0.035570625 \\
\hline RP11-508 M8.1 & Uncharacterized & 10.7 & $1.85 \mathrm{E}-04$ & 0.039536736 \\
\hline CCL3 & $\begin{array}{l}\text { Chemokine (C-C motif) ligand 3. Its related pathways are Signaling } \\
\text { by GPCR and TGF-Beta Pathway. }\end{array}$ & 31 & $2.13 \mathrm{E}-04$ & 0.043901777 \\
\hline LL22NC03-63E9.3 & Uncharacterized LOC648691, affiliated with the ncRNA class. & -22.2 & $2.30 \mathrm{E}-04$ & 0.045120747 \\
\hline RP11-180P8.3 & Uncharacterized & 46.1 & $2.36 \mathrm{E}-04$ & 0.045120747 \\
\hline RP11-213H15.3 & Uncharacterized & 11.1 & $2.56 \mathrm{E}-04$ & 0.046011494 \\
\hline
\end{tabular}


Table 2 DEGs in plasma before HCV infection in clearance group compared to those in chronically infected group (Continued)

\begin{tabular}{lllc}
\hline IL17D & Interleukin 17D. Its related pathways are IL-17 Family & 40 & $2.58 \mathrm{E}-04$ \\
& Signaling Pathways and IL-17 Family Signaling Pathways. & 0.046011494 \\
AC016831.7 & Uncharacterized & 5.8 & $2.71 \mathrm{E}-04$ \\
NFKBIL1 & $\begin{array}{l}\text { Nuclear factor of kappa light polypeptide gene enhancer in } \\
\text { B-cells inhibitor-like 1 }\end{array}$ & 8.046888832 \\
SLC2A6 & $\begin{array}{l}\text { Solute carrier family 2, member 6. Its related pathways are } \\
\text { PAK Pathway and HIF1Alpha Pathway. }\end{array}$ & 7.9 & 0.049193252 \\
& & & $3.03 \mathrm{E}-04$ \\
\end{tabular}

${ }^{\mathrm{a}} D E G$ Differentially expressed gene

signaling, p53 signaling, PI3K/AKT signaling, and acute phase response signaling.

\section{Discussion}

Unraveling the mechanism of spontaneous HCV clearance after an acute phase of infection in HIV infected individuals provides valuable information that will be informative for the development of a vaccine against HCV. In a genome-wide association study of $\mathrm{HCV}$ infected individuals, SNPs in the region of the IL28B gene, encoding interferon- $\lambda-3$, were shown to be associated with the outcome of $\mathrm{HCV}$ infection; the $\mathrm{CC}$ genotype enhances spontaneous resolution of $\mathrm{HCV}$ infection, whereas those with the TT genotype showed a great propensity to develop chronic HCV infection $[15,16]$. In the current study we could not detect any significant relationship between $\mathrm{CC}$ genotype and HCV clearance, because the CC genotype was found in four of the five clearance subjects and four of the eight chronically HCV infected subjects. The distribution of the genotypes in the infected subjects suggests that other factors beside the IL28B SNPs play a role in the spontaneous $\mathrm{HCV}$ clearance in the co-infected individuals [14, 18, 27]. However, the small sample size in our study also could explain our failure to detect an association between IL28B polymorphisms and $\mathrm{HCV}$ clearance.

Recent advances in RNA sequencing technology have provided opportunities to comprehensively and quantitatively sequence RNA and examine virus-host interactions at the transcriptional level. Two studies have reported transcriptomes analysis of liver tissues of $\mathrm{HCV}$ infected chimpanzees with spontaneous viral clearance or chronic infection outcomes. Nanda et al [18] reported that early induction of the genes associated with cell proliferation and immune activation, especially interleukin binding factor 3 (ILF3) and cytotoxic granule associated RNA binding protein (TIA1), was associated with subsequent HCV clearance in infected chimpanzees. Suet et al [28] reported that cellular genes induced by IFN- $\gamma$ and those involved in antigen processing/presentation and the adaptive immune response were associated with $\mathrm{HCV}$ clearance. These reports suggest that host innate/adaptive immune responses play an important role in HCV clearance. However, studies on the transcriptome of liver tissues from $\mathrm{HIV} / \mathrm{HCV}$ co-infected
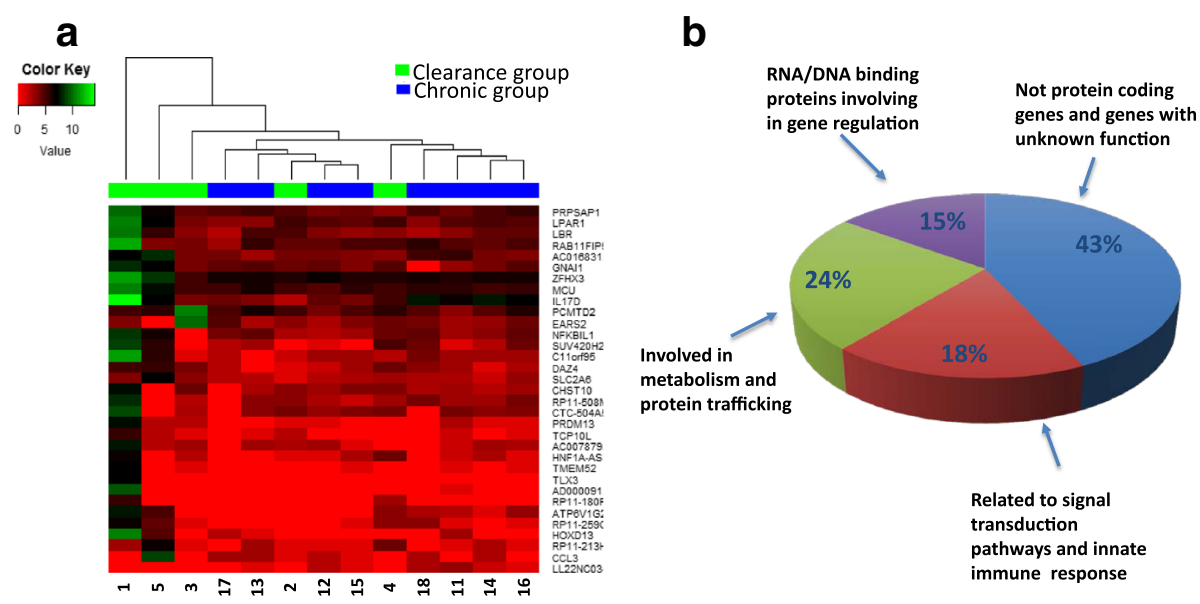

Fig. 2 Differentially expressed genes before HCV infection in clearance group compared to chronic group. a The heatmap was generated with the statistical differentially expressed genes between clearance group and chronic group before HCV infection. The numbers on X-axis represent individual subjects. Green stands for the clearance group and blue stands for the chronic group. $\mathbf{b}$ Pie chart illustrates the percentage of the DEGs, which encode proteins involved in different functions 
Table 3 DEGs in plasma after HCV infection in clearance group compared to those in chronically infected group

\begin{tabular}{|c|c|c|c|c|}
\hline $\mathrm{DEGs}^{\mathrm{a}}$ & Function & Fold difference & $P$ value & FDR \\
\hline MIXL1 & $\begin{array}{l}\text { Mix paired-like homeobox. Among its related pathways are } \\
\text { Cardiac Progenitor differentiation and Adipogenesis. }\end{array}$ & 142.7 & $3.52 \mathrm{E}-07$ & 0.00142576 \\
\hline SLC30A3 & $\begin{array}{l}\text { Solute carrier family } 30 \text { (zinc transporter), member 3. Its related } \\
\text { pathways are Transport of glucose and other sugars, bile salts } \\
\text { and organic acids, metal ions and amine compounds and } \\
\text { Transport of glucose and other sugars, bile salts and organic } \\
\text { acids, metal ions and amine compounds. }\end{array}$ & 23.8 & $5.32 \mathrm{E}-07$ & 0.00142576 \\
\hline SFRP5 & $\begin{array}{l}\text { Secreted frizzled-related protein 5. Its related pathways are Wnt } \\
\text { signaling pathway (KEGG) (Wnt proteins are secreted morphogens } \\
\text { that are required for basic developmental processes) and } \\
\text { Non-Canonical Wnt Pathway. }\end{array}$ & 53.4 & $2.05 \mathrm{E}-06$ & 0.00365475 \\
\hline AC007879.2 & Uncharacterized & 13.8 & $1.45 \mathrm{E}-05$ & 0.00595947 \\
\hline AD000091.2 & Uncharacterized & 283.2 & $1.05 \mathrm{E}-05$ & 0.00595947 \\
\hline C12orf44 & Autophagy related 101 & 18.9 & 8.91E-06 & 0.00595947 \\
\hline HNF1A-AS1 & HNF1A antisense RNA 1 affiliated with the antisense RNA class. & 48.4 & $1.32 \mathrm{E}-05$ & 0.00595947 \\
\hline LBR & $\begin{array}{l}\text { Lamin B receptor. Its related pathways are Metabolism } \\
\text { and Metabolism. }\end{array}$ & 70.9 & 1.36E-05 & 0.00595947 \\
\hline MTMR1 & $\begin{array}{l}\text { Myotubularin related protein 1. Its related pathways are } \\
\text { Metabolism and Metabolism. }\end{array}$ & 20.4 & $1.44 \mathrm{E}-05$ & 0.00595947 \\
\hline NLRP13 & NLR family, pyrin domain containing 13 & 10.9 & 5.86E-06 & 0.00595947 \\
\hline PPP1R3G & $\begin{array}{l}\text { Protein phosphatase } 1 \text {, regulatory subunit } 3 \mathrm{G} \text {. It is related to } \\
\text { protein phosphatase binding and glycogen binding. }\end{array}$ & 82.1 & $1.25 \mathrm{E}-05$ & 0.00595947 \\
\hline PRPSAP1 & $\begin{array}{l}\text { Phosphoribosyl pyrophosphate synthetase-associated protein } 1 . \\
\text { This gene is related to magnesium ion binding and enzyme } \\
\text { inhibitor activity. }\end{array}$ & 56.8 & $1.29 \mathrm{E}-05$ & 0.00595947 \\
\hline RAB11FIP5 & $\begin{array}{l}\text { RAB11 family interacting protein } 5 \text { (class I). Its related pathways } \\
\text { are Endocytosis and Delta508-CFTR traffic / ER-to-Golgi in CF. }\end{array}$ & 53.4 & $1.01 \mathrm{E}-05$ & 0.00595947 \\
\hline RP11-436F21.1 & Uncharacterized & 9.6 & $1.93 \mathrm{E}-05$ & 0.00740049 \\
\hline C11orf95 & $\begin{array}{l}\text { Chromosome } 11 \text { open reading frame } 95 \text {. Diseases associated } \\
\text { with C11orf95 include ependymoma and chondroid lipoma. }\end{array}$ & 119.4 & $2.56 \mathrm{E}-05$ & 0.00913053 \\
\hline HOXD13 & $\begin{array}{l}\text { Homeobox D13. This gene is related to sequence-specific DNA } \\
\text { binding transcription factor activity and chromatin binding. }\end{array}$ & 96 & 3.07E-05 & 0.01028157 \\
\hline RP11-508M8.1 & Uncharacterized & 14.6 & $3.46 \mathrm{E}-05$ & 0.0109017 \\
\hline CTC-504A5.1 & Affiliated with the ncRNA class & 9.9 & $3.82 \mathrm{E}-05$ & 0.01135634 \\
\hline IRS4 & $\begin{array}{l}\text { Insulin receptor substrate } 4 \text {. Its related pathways are Signaling by } \\
\text { GPCR and Insulin receptor signaling cascade. }\end{array}$ & 54.4 & $5.62 \mathrm{E}-05$ & 0.01466991 \\
\hline MANEAL & Mannosidase, endo-alpha-like. It is related to hydrolase activity. & 14.7 & $5.95 \mathrm{E}-05$ & 0.01466991 \\
\hline MCU & $\begin{array}{l}\text { Mitochondrial calcium uniporter. It is related to calcium channel } \\
\text { activity and uniporter activity. }\end{array}$ & 11.9 & $6.03 \mathrm{E}-05$ & 0.01466991 \\
\hline SUV42OH2_1 & Uncharacterized & 18.4 & $5.71 \mathrm{E}-05$ & 0.01466991 \\
\hline SLC25A18 & $\begin{array}{l}\text { Solute carrier family } 25 \text { (glutamate carrier), member } 18 \text {. It is related } \\
\text { to this gene include symporter activity. }\end{array}$ & 86.7 & $6.39 \mathrm{E}-05$ & 0.01489091 \\
\hline GNAI1 & $\begin{array}{l}\text { Guanine nucleotide binding protein (G protein), alpha inhibiting } \\
\text { activity polypeptide 1. Its related pathways are GPCR Pathway } \\
\text { and GPCR Pathway. }\end{array}$ & 10.8 & $6.69 \mathrm{E}-05$ & 0.01492573 \\
\hline ADPRHL1 & $\begin{array}{l}\text { ADP-ribosylhydrolase like } 1 \text {. It is related to magnesium ion binding } \\
\text { and ADP-ribosylarginine hydrolase activity. }\end{array}$ & 7.3 & $9.39 \mathrm{E}-05$ & 0.01676156 \\
\hline CMTM4 & $\begin{array}{l}\text { CKLF-like MARVEL transmembrane domain containing } 4 \text {. It is related } \\
\text { to cytokine activity. }\end{array}$ & 16 & $9.17 \mathrm{E}-05$ & 0.01676156 \\
\hline F10 & $\begin{array}{l}\text { Coagulation factor X. it is related the pathways of Hemostasis and } \\
\text { Formation of Fibrin Clot (Clotting Cascade). }\end{array}$ & 11.4 & $8.76 \mathrm{E}-05$ & 0.01676156 \\
\hline LPAR1 & Lysophosphatidic acid receptor 1. Its related pathways are & 9.6 & 8.50E-05 & 0.01676156 \\
\hline
\end{tabular}


Table 3 DEGs in plasma after HCV infection in clearance group compared to those in chronically infected group (Continued)

\begin{tabular}{|c|c|c|c|c|}
\hline LYSMD4 & LysM, putative peptidoglycan-binding, domain containing 4 & 10.3 & $8.30 \mathrm{E}-05$ & 0.01676156 \\
\hline RP11-886H22.1 & Uncharacterized & 9.3 & $9.38 \mathrm{E}-05$ & 0.01676156 \\
\hline ATP12A & $\begin{array}{l}\text { ATPase, } \mathrm{H}+/ \mathrm{K}+\text { transporting, nongastric, alpha polypeptide. } \\
\text { It is related to the pathways of lon channel transport and } \\
\text { Transport of glucose and other sugars, bile salts and organic } \\
\text { acids, metal ions and amine compounds. }\end{array}$ & 10.2 & $1.22 \mathrm{E}-04$ & 0.01943478 \\
\hline POU4F1-AS1 & RNF219 antisense RNA 1 & 8.1 & $1.23 \mathrm{E}-04$ & 0.01943478 \\
\hline PRDM13 & $\begin{array}{l}\text { PR domain containing } 13 \text {. This gene related to } \\
\text { methyltransferase activity. }\end{array}$ & 30.5 & 1.23E-04 & 0.01943478 \\
\hline ZXDA & $\begin{array}{l}\text { Zinc finger, } \mathrm{X} \text {-linked, duplicated } \mathrm{A} \text {. it is related to sequence-specific } \\
\text { DNA binding transcription factor activity and } \mathrm{C} 2 \mathrm{H} 2 \text { zinc finger } \\
\text { domain binding. }\end{array}$ & 45.3 & 1.17E-04 & 0.01943478 \\
\hline AC009495.4 & Uncharacterized & 8.9 & $1.59 \mathrm{E}-04$ & 0.02368413 \\
\hline RP11-410N8.1 & Uncharacterized & 29.8 & $1.55 \mathrm{E}-04$ & 0.02368413 \\
\hline ANKRD34B & Ankyrin repeat domain 34B & 10.4 & $2.00 \mathrm{E}-04$ & 0.02675171 \\
\hline DPY19L3 & $\begin{array}{l}\text { Dpy-19-like } 3 . \text { It is related to transferase activity, transferring } \\
\text { glycosyl groups. }\end{array}$ & 5.2 & $2.08 \mathrm{E}-04$ & 0.02675171 \\
\hline LINC00609 & long intergenic non-protein coding RNA 609 & 8.9 & $2.08 \mathrm{E}-04$ & 0.02675171 \\
\hline RP11-180P8.3 & Uncharacterized & 96.5 & $2.15 \mathrm{E}-04$ & 0.02675171 \\
\hline RP11-492E3.2 & Uncharacterized & -8.3 & 2.05E-04 & 0.02675171 \\
\hline TLX3 & $\begin{array}{l}\text { T-cell leukemia homeobox } 3 \text {. Its related pathways are Transcriptional } \\
\text { misregulation in cancer and SIDS Susceptibility Pathways. }\end{array}$ & 83.1 & $1.96 \mathrm{E}-04$ & 0.02675171 \\
\hline ZFHX3 & $\begin{array}{l}\text { Zinc finger homeobox 3. Its related pathways are Transcriptional } \\
\text { Regulatory Network in Embryonic Stem Cell. }\end{array}$ & 12.5 & $2.11 \mathrm{E}-04$ & 0.02675171 \\
\hline SOHLH1 & $\begin{array}{l}\text { Spermatogenesis and oogenesis specific basic helix-loop-helix } 1 . \\
\text { It is related to sequence-specific DNA binding transcription factor } \\
\text { activity and protein dimerization activity. }\end{array}$ & 15.2 & $2.54 \mathrm{E}-04$ & 0.03086759 \\
\hline SLC51A & $\begin{array}{l}\text { Solute carrier family 51, alpha subunit. It is related the Bile secretion } \\
\text { and Drug Induction of Bile Acid Pathway. }\end{array}$ & 7.6 & 2.60E-04 & 0.03093234 \\
\hline TCF15 & $\begin{array}{l}\text { Transcription factor } 15 \text { (basic helix-loop-helix). It is related to ERK } \\
\text { Signaling and ERK Signaling pathways. }\end{array}$ & 8.8 & 2.74E-04 & 0.03191743 \\
\hline RP11-118B18.1 & Uncharacterized & 6.5 & $3.08 \mathrm{E}-04$ & 0.03504717 \\
\hline ATP6V1G2 & $\begin{array}{l}\text { ATPase, } \mathrm{H}+\text { transporting, lysosomal } 13 \mathrm{kDa} \text {, } \mathrm{V} 1 \text { subunit } \mathrm{G} 2 \text {. } \\
\text { A multisubunit enzyme that mediates acidification of intracellular } \\
\text { compartments of eukaryotic cells. }\end{array}$ & 23.3 & $3.68 \mathrm{E}-04$ & 0.04059745 \\
\hline RP11-435M3.2 & Uncharacterized & 15.9 & $3.71 \mathrm{E}-04$ & 0.04059745 \\
\hline C4orf32 & A Protein Coding gene & 4.4 & 4.10E-04 & 0.04218642 \\
\hline ZC3H8 & $\begin{array}{l}\text { Zinc finger CCCH-type containing } 8 \text {. It is related to sequence-specific } \\
\text { DNA binding transcription factor activity and sequence-specific } \\
\text { DNA binding. }\end{array}$ & 7 & $3.94 \mathrm{E}-04$ & 0.04218642 \\
\hline ZXDB & A protein coding gene. It is related to nucleic acid binding. & 32.1 & 4.03E-04 & 0.04218642 \\
\hline CHST10 & $\begin{array}{l}\text { Carbohydrate sulfotransferase 10. Its related pathways are Other types } \\
\text { of O-glycan biosynthesis and Biological oxidations. }\end{array}$ & 6.6 & $4.38 \mathrm{E}-04$ & 0.04421968 \\
\hline RP11-7F17.5 & Uncharacterized & -5.1 & $4.50 \mathrm{E}-04$ & 0.04426996 \\
\hline TMEM52 & Transmembrane protein 52 & 108.9 & 4.55E-04 & 0.04426996 \\
\hline NEURL & $\begin{array}{l}\text { A Protein Coding gene. It is related the pathways of Signaling by } \\
\text { GPCR and Disease. }\end{array}$ & 6 & $4.68 \mathrm{E}-04$ & 0.0447815 \\
\hline AP3B1 & $\begin{array}{l}\text { A protein coding gene. It is related to the pathway of Lysosome } \\
\text { and Clathrin derived vesicle budding. }\end{array}$ & 7.8 & $5.28 \mathrm{E}-04$ & 0.04960697 \\
\hline
\end{tabular}




\section{a}

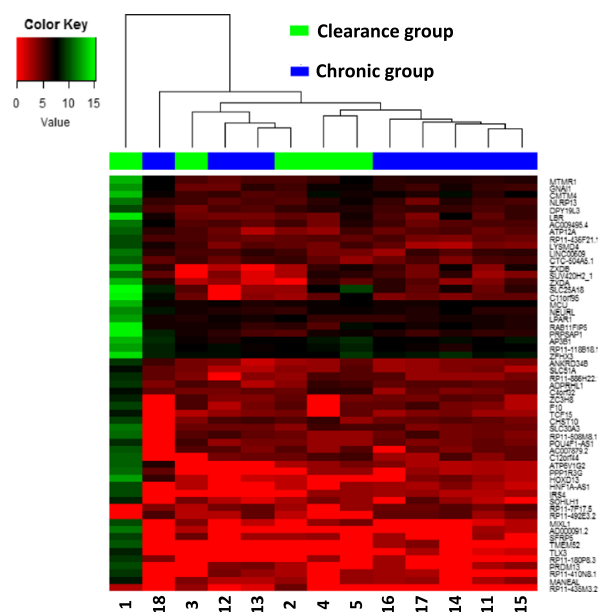

b

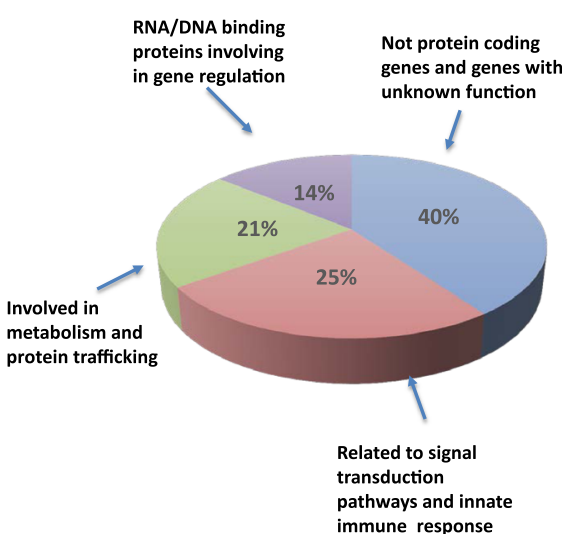

Fig. 3 Differentially expressed genes after HCV infection in clearance group compared to chronic group. a The heatmap was generated with the statistical differentially expressed genes between clearance group and chronic group after HCV infection. The numbers on X-axis represent individual subjects. Green stands for the clearance group and blue stands for the chronic group. $\mathbf{b}$ The pie chart illustrates the percentage of the DEGs, which encode proteins involved in different functions

humans with different outcomes are very limited. Due to lack of available liver tissues, we focused on determining transcriptomes in plasma from $\mathrm{HIV} / \mathrm{HCV}$ co-infected subjects with and without $\mathrm{HCV}$ clearance, since the quantity and characteristics of RNAs in plasma may reflect concurrent pathogenic changes in host liver tissues.

The availability of sequential plasma samples with defined onset and disease outcomes of HCV infection in highly characterized HIV-infected subjects from the MACS [25] provided us with a unique opportunity to identify, for the first time, the cellular transcripts that may be related to HCV clearance. Application of RNA sequencing technology in plasma has allowed us to determine such differentially expressed transcripts between subjects who cleared HCV and those who remained chronically infected after acute infection. In addition, the analysis of samples collected before and after acquisition of HCV infection provided information on cellular transcripts that may be associated with $\mathrm{HCV}$ clearance. Plasma transcriptome analysis of mRNA in subjects who cleared $\mathrm{HCV}$ and those who remained chronically HCV infected before and after HCV infection identified 12 DEGs that are uniquely expressed before HCV infection and a number of these genes and their upstream regulators are associated with innate immune response in the clearance group. For instance,

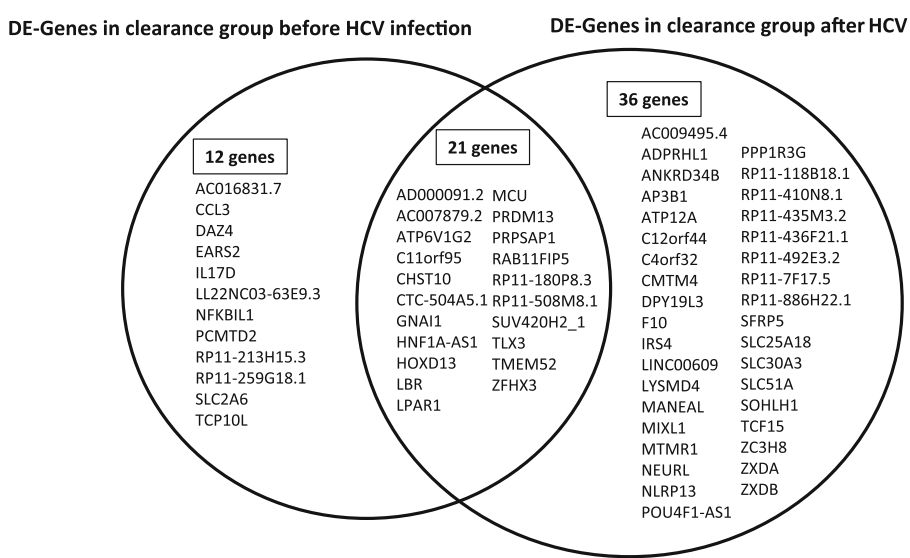

Fig. 4 Intersectional analysis of the differentially expressed genes before and after HCV infection in clearance group and Chronic group. The diagram was generated with the statistical differentially expressed genes between clearance group and chronic group before and after HCV infection 
a

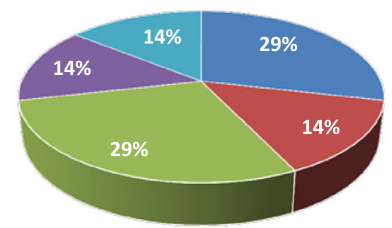

- Hematological system development \& function

- Immune cell trafficking

- Hematopoesis

- Humoral Immune response

- Cell mediated immune response

b

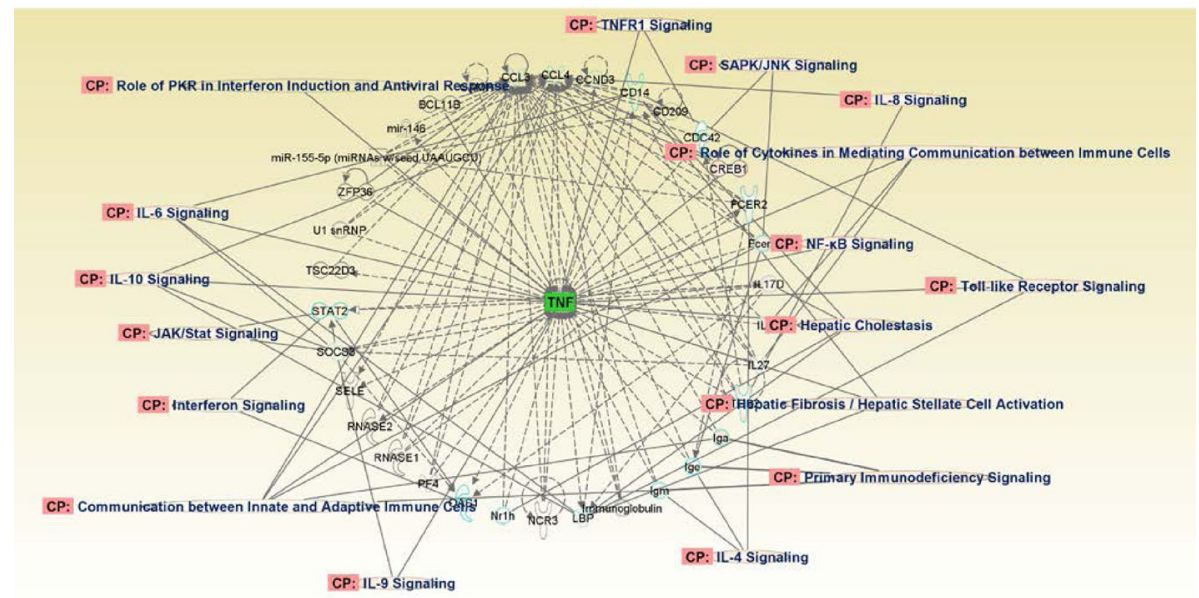

Fig. 5 Physiological system development and function of unique DEG in clearance group before infection. a Pie chart demonstrates that majority of DEGs seen before HCV infection in the clearance group is clustered in immune mediated pathways. b Predicted interaction networks of mRNAs and associated pathways were identified using the DEGs in clearance compared to chronic group before HCV infection. The interactions between genes were identified using Ingenuity Pathway Analysis

IL17D, a member of IL17 family, plays a major regulatory role in host defense and inflammatory diseases [29]. The NFKBIL1 gene encodes a divergent member of the I-kappa-B family of proteins and is involved in the regulation of innate immune response by negatively regulating TLR and interferon regulatory factor (IRF) signaling pathways. In addition, the NFKBIL1 gene has a role in negative regulation of transcriptional activation of NF-kB genes in response to pro-inflammatory stimuli [30]. CCL3, a chemokine, has been shown to increase NK activity [31]. This goes along with observation that subjects who resolved $\mathrm{HCV}$ infection had a higher frequency of HCVspecific interferon-gamma-producing T-cells $(P=0.017)$ and cytotoxic NK-cells $(P=0.005)$, compared to patients who became chronically infected [27]. In addition, in $\mathrm{HCV}$ infected patients treated with interferon- $\alpha$ and ribavirin, increases in MIP- $1 \alpha$, MIP- $1 \beta$ and RANTES levels after $24 \mathrm{~h}$ of treatment were exclusively observed in the group that showed a sustained virological response, suggesting an antiviral role of CCL3 [32]. Furthermore, IPA analysis suggests that cytokine signaling (such as IL-1, IL-4, IL-6, IL-8, IL-9, IL-10, TNFR1, interferon), TLR signaling, MAPK signaling, NF- $\mathrm{BB}$ signaling, communication between innate and adaptive immune cells, and ELF3 could be involved in HCV clearance.

\section{Conclusions}

Plasma RNA sequencing has identified the transcripts that are significantly associated with $\mathrm{HCV}$ clearance and are found to be expressed prior to infection. Some of the transcripts are involved in innate immune function. These results suggest that subjects who spontaneously clear HCV may have the transcripts that modulate forms of immunity that confer resistance to chronic infection with $\mathrm{HCV}$. Further studies with longitudinal samples from HCV infected patients who cleared HCV infection, and those who became chronically infected may provide more definitive information about the nature of these inherited traits. 


\section{Abbreviations}

cDNA: Complementary DNA; DEG-A: Differentially expressed genes after HCV infection; DEG-B: Differentially expressed genes before HCV infection; DEGs: Differentially expressed genes; FDR: False Discovery Rate; HCV: Hepatitis C virus; HIV: Human immunodeficiency virus; IL28B: Polymorphisms in interleukin 28B; ILF3: Interleukin binding factor 3; MACS: The Multicenter AIDS Cohort Study; TLR: Toll like receptor; TR1A: HCV clearance group after HCV infection; TR1B: HCV clearance group before HCV infection; TR2A: Chronically HCV infected group after HCV infection; TR2B: Chronically HCV infected group before HCV infection

\section{Acknowledgements}

Data in this article were collected by the Multicenter AIDS Cohort Study (MACS) with centers (principal investigators) at The Johns Hopkins Bloomberg School of Public Health (Joseph B. Margolick, Lisa P. Jacobson), Howard Brown Health Center, Feinberg School of Medicine, Northwestern University, and Cook County Bureau of Health Services (John P. Phair, Steven M. Wolinsky), University of California, Los Angeles (Roger Detels), and University of Pittsburgh (Charles R. Rinaldo).

\section{Funding}

The MACS is funded by the National Institute of Allergy and Infectious Diseases, with additional supplemental funding from the National Cancer Institute (UO1- Al-35042, UL1-RR025005, UO1-Al-35043, UO1-Al-35039, UO1Al-35040, UO1-Al-35041). Website located at https://statepi.jhsph.edu/macs/ macs.html.

\section{Availability of data and materials}

Data are held by the Center for Analysis and Management of the Multicenter AIDS Cohort Study (CAMACS). For access to the MACS data, please contact CAMACS at https://statepi.jhsph.edu/macs/macs.html.

\section{Authors' contributions}

YC and PG conceived of the study. CS and DG provided assistance with experimental design and sample section. CR, ES, JM, VS, and OM contributed samples for the study. YC, CS, AA, SK and MD designed and performed the laboratory experiments as well as analyzed the results. YC and PG drafted the original manuscript. All authors read and approved the final manuscript.

\section{Competing interests}

The authors declare that they have no competing interests.

\section{Consent for publication}

Not applicable.

\section{Ethics approval and consent to participate}

The study was approved by the Institutional Review Board (IRB)/ethical standards committee in University of Pittsburgh, University of California Los Angeles, Northwestern University and John Hopkins University. Written informed consent was obtained from all subjects participating in the study.

\section{Author details}

${ }^{1}$ Department of Infectious Diseases and Microbiology, Graduate School of Public Health, University of Pittsburgh, 2138 Parran Hall, 130 DeSoto Street, Pittsburgh, Pa 15261, USA. ²Department of Pathology, VA Hospital, Pittsburgh, Pa, USA. ${ }^{3}$ Department of Molecular Microbiology and Immunology, Bloomberg School of Public Health, Johns Hopkins University, Baltimore, MD, USA. ${ }^{4}$ Division of Infectious Diseases, School of Medicine, Northwestern University, Chicago, IL, USA. ${ }^{5}$ Department of Epidemiology, UCLA Fielding School of Public Health, and Departments of Obstetrics \& Gynecology and Microbiology, Immunology \& Molecular Genetics, David Geffen School of Medicine at UCLA, Los Angeles, CA, USA.

Received: 22 June 2016 Accepted: 16 November 2016

\section{Published online: 22 November 2016}

\section{References}

1. El-Serag HB. Hepatocellular carcinoma and hepatitis $\mathrm{C}$ in the United States. Hepatology. 2002;36(5 Suppl 1):S74-83.

2. Sherman KE, Rouster SD, Chung RT, Rajicic N. Hepatitis C Virus prevalence among patients infected with Human Immunodeficiency Virus: a cross-sectional analysis of the US adult AIDS Clinical Trials Group. Clin Infect Dis. 2002;34(6):831-7.
3. Ghosn J, Deveau C, Goujard C, Garrigue I, Saichi N, Galimand J, Nagy Z, Rouzioux C, Meyer L, Chaix ML. Increase in hepatitis C virus incidence in HIV-1-infected patients followed up since primary infection. Sex Transm Infect. 2006;82(6):458-60.

4. Urbanus AT, van de Laar TJ, Stolte IG, Schinkel J, Heijman T, Coutinho RA, Prins $M$. Hepatitis $C$ virus infections among HIV-infected men who have sex with men: an expanding epidemic. AIDS. 2009;23(12):F1-7.

5. Micallef JM, Kaldor JM, Dore GJ. Spontaneous viral clearance following acute hepatitis C infection: a systematic review of longitudinal studies. J Viral Hepat. 2006;13(1):34-41.

6. Weber R, Sabin CA, Friis-Moller N, Reiss P, El-Sadr WM, Kirk O, Dabis F, Law MG, Pradier C, De Wit S, et al. Liver-related deaths in persons infected with the human immunodeficiency virus: the D:A:D study. Arch Intern Med. 2006; 166(15):1632-41.

7. Lewden C, Salmon D, Morlat P, Bevilacqua S, Jougla E, Bonnet F, Heripret L, Costagliola D, May T, Chene G, et al. Causes of death among human immunodeficiency virus (HIV)-infected adults in the era of potent antiretroviral therapy: emerging role of hepatitis and cancers, persistent role of AIDS. Int J Epidemiol. 2005:34(1):121-30.

8. Sahasrabuddhe W, Shiels MS, McGlynn KA, Engels EA. The risk of hepatocellular carcinoma among individuals with acquired immunodeficiency syndrome in the United States. Cancer. 2012;118(24): 6226-33.

9. Seaberg EC, Witt MD, Jacobson LP, Detels R, Rinaldo CR, Margolick JB, Young S, Phair JP, Thio CL. Spontaneous Clearance of the Hepatitis C Virus Among Men Who Have Sex With Men. Clin Infect Dis. 2015;61(9):1381-8.

10. Witt MD, Seaberg EC, Darilay A, Young S, Badri S, Rinaldo CR, Jacobson LP, Detels $R$, Thio $C L$. Incident hepatitis $C$ virus infection in men who have sex with men: a prospective cohort analysis, 1984-2011. Clin Infect Dis. 2013; 57(1):77-84

11. Alric L, Fort M, Izopet J, Vinel JP, Bureau C, Sandre K, Charlet JP, Beraud M, Abbal M, Duffaut M. Study of host- and virus-related factors associated with spontaneous hepatitis C virus clearance. Tissue Antigens. 2000;56(2):154-8.

12. Balagopal A, Thomas DL, Thio CL. IL28B and the control of hepatitis $C$ virus infection. Gastroenterology. 2010;139(6):1865-76.

13. Mosbruger TL, Duggal P, Goedert JJ, Kirk GD, Hoots WK, Tobler LH, Busch M, Peters MG, Rosen HR, Thomas DL, et al. Large-scale candidate gene analysis of spontaneous clearance of hepatitis C virus. J Infect Dis. 2010;201(9):1371-80.

14. Beinhardt S, Aberle JH, Strasser M, Dulic-Lakovic E, Maieron A, Kreil A, Rutter K, Staettermayer AF, Datz C, Scherzer TM, et al. Serum level of IP-10 increases predictive value of IL28B polymorphisms for spontaneous clearance of acute HCV infection. Gastroenterology. 2012;142(1):78-85-e72.

15. Bibert S, Roger T, Calandra T, Bochud M, Cerny A, Semmo N, Duong FH, Gerlach T, Malinverni R, Moradpour D, et al. IL28B expression depends on a novel TT/-G polymorphism which improves HCV clearance prediction. J Exp Med. 2013;210(6):1109-16.

16. Thomas DL, Thio CL, Martin MP, Qi Y, Ge D, O'Huigin C, Kidd J, Kidd K, Khakoo SI, Alexander G, et al. Genetic variation in IL28B and spontaneous clearance of hepatitis C virus. Nature. 2009:461(7265):798-801.

17. Tillmann HL, Thompson AJ, Patel K, Wiese M, Tenckhoff H, Nischalke HD, Lokhnygina Y, Kullig U, Gobel U, Capka E, et al. A polymorphism near IL28B is associated with spontaneous clearance of acute hepatitis $C$ virus and jaundice. Gastroenterology. 2010;139(5):1586-92. 1592 e1581.

18. Nanda S, Havert MB, Calderon GM, Thomson M, Jacobson C, Kastner D, Liang TJ. Hepatic transcriptome analysis of hepatitis $C$ virus infection in chimpanzees defines unique gene expression patterns associated with viral clearance. PLoS One. 2008;3(10):e3442.

19. Martin MP, Carrington M. Immunogenetics of HIV disease. Immunol Rev 2013;254(1):245-64.

20. Chen YJ, Zhu JM, Wu H, Fan J, Zhou J, Hu J, Yu Q, Liu TT, Yang L, Wu CL, et al. Circulating microRNAs as a Fingerprint for Liver Cirrhosis. PLoS One. 2013;8(6):e66577.

21. Oloomi M, Bouzari S, Mohagheghi MA, Khodayaran-Tehrani H. Molecular markers in peripheral blood of Iranian women with breast cancer. Cancer Microenviron. 2013;6(1):109-16

22. Shen J, Wang H, Wei J, Yu L, Xie L, Qian X, Zou Z, Liu B, Guan W. Thymidylate synthase mRNA levels in plasma and tumor as potential predictive biomarkers for raltitrexed sensitivity in gastric cancer. Int J Cancer. 2012;131(6):E938-945.

23. Tzimagiorgis G, Michailidou EZ, Kritis A, Markopoulos AK, Kouidou S. Recovering circulating extracellular or cell-free RNA from bodily fluids. Cancer Epidemiol. 2011;35(6):580-9. 
24. Wang W, Zhang X, Xu Y, Di Bisceglie AM, Fan X. Viral categorization and discovery in human circulation by transcriptome sequencing. Biochem Biophys Res Commun. 2013;436(3):525-9.

25. Kaslow RA, Ostrow DG, Detels R, Phair JP, Polk BF, Rinaldo Jr CR. The Multicenter AIDS Cohort Study: rationale, organization, and selected characteristics of the participants. Am J Epidemiol. 1987;126(2):310-8.

26. Soto-Rivera J, Patterson BK, Chen Y, Shen C, Ratner D, Ding M, Tumne A, Gupta P. Study of HIV-1 transmission across cervical mucosa to tonsil tissue cells using an organ culture. Am J Reprod Immunol. 2013;69(1):52-63.

27. Riva A, Laird M, Casrouge A, Ambrozaitis A, Williams R, Naoumov NV, Albert ML, Chokshi S. Truncated CXCL10 is associated with failure to achieve spontaneous clearance of acute hepatitis C infection. Hepatology. 2014;60(2):487-96.

28. Su Al, Pezacki JP, Wodicka L, Brideau AD, Supekova L, Thimme R, Wieland S, Bukh J, Purcell RH, Schultz PG, et al. Genomic analysis of the host response to hepatitis C virus infection. Proc Natl Acad Sci U S A. 2002;99(24):15669-74.

29. O'Sullivan T, Saddawi-Konefka R, Gross E, Tran M, Mayfield SP, Ikeda H, Bui JD. Interleukin-17D mediates tumor rejection through recruitment of natural killer cells. Cell Rep. 2014;7(4):989-98.

30. Oeckinghaus A, Hayden MS, Ghosh S. Crosstalk in NF-kappaB signaling pathways. Nat Immunol. 2011;12(8):695-708.

31. Robertson MJ. Role of chemokines in the biology of natural killer cells. J Leukoc Biol. 2002;71(2):173-83.

32. Zhang Y, Guo D, Zhao Y, Chen X, Ma L, Jin Y, Yan H, Wu H, Wei L, Dong T, et al. The effect of cytokine profiles on the viral response to re-treatment in antiviral-experienced patients with chronic hepatitis $\mathrm{C}$ virus infection. Antiviral Res. 2011;92(2):247-54

\section{Submit your next manuscript to BioMed Central} and we will help you at every step:

- We accept pre-submission inquiries

- Our selector tool helps you to find the most relevant journal

- We provide round the clock customer support

- Convenient online submission

- Thorough peer review

- Inclusion in PubMed and all major indexing services

- Maximum visibility for your research

Submit your manuscript at www.biomedcentral.com/submit 